Marquette University

e-Publications@Marquette

Biological Sciences Faculty Research and

Publications

Biological Sciences, Department of

$1-1-2012$

Perturbing Microtubule Integrity Blocks AMPActivated Protein Kinase-Induced Meiotic Resumption in Cultured Mouse Oocytes

$\mathrm{Ru} \mathrm{Ya}$

Marquette University

Stephen Downs

Marquette University, stephen.downs@marquette.edu

Published version. Zygote (2012): 1-12. DOI. (C) 2012 Cambridge University Press. Used with permission. 


\title{
Perturbing Microtubule Integrity Blocks AMP-Activated Protein Kinase-Induced Meiotic Resumption in Cultured Mouse Oocytes
}

\author{
Ru Ya \\ Department of Biological Sciences, Marquette University \\ Milwaukee, WI \\ Stephen M. Downs \\ Department of Biological Sciences, Marquette University \\ Milwaukee, WI
}

\begin{abstract}
AMP-activated protein kinase (AMPK) is an important cellular energy sensor that is activated by a low AMP-to-ATP ratio. AMPK is involved in meiotic induction of mouse oocytes and also promotes the completion of maturation, but suppress premature activation. This study was conducted to further examine the activity and localization of AMPK in relation to microtubule (MT) integrity. Immunostaining with tubulin revealed that active AMPK localized with gamma tubulin during metaphase I and II, while it localized at the spindle midzone during anaphase. This discrete localization pattern was dependent on MT integrity. Treatment with nocodazole, which depolymerized spindle MTs, led to disruption of proper spindle pole localization of active AMPK. In contrast, active AMPK was localized at each pole and with small asters when treated with paclitaxel, which induced excessive polymerization of spindle MTs. Disturbing spindle integrity not only influenced active AMPK localization, but also blocked AMPK activity, as both hormone- and AMPK activator- induced oocyte maturation were blocked by


NOT THE PUBLISHED VERSION; this is the author's final, peer-reviewed manuscript. The published version may be accessed by following the link in the citation at the bottom of the page.

MT-disrupting agents. In concert with these data, the treatments inhibited active AMPK germinal vesicle staining as well, which appears before germinal vesicle breakdown (GVB) in meiotically induced oocytes. Targeting actin filament polymerization had only a marginal effect on meiotic induction. Although oocytes stimulated by AMPK activator increased the rate of GVB, spindle formation and PB extrusion, blocking AMPK activity did not influence peripheral movement of the spindle. These data suggest that the meiosisinducing action and localization of AMPK are regulated by MT spindle integrity during mouse oocyte maturation.

\section{Introduction}

Mammalian oocyte maturation refers to the developmental period between germinal vesicle breakdown and formation of the first polar body and involves dynamic changes within the cytoskeletal network. Initially, the meiotic spindle forms at a position slightly offcenter, where the germinal vesicle (GV) was originally located. After germinal vesicle breakdown (GVB), microtubules start polymerizing around the condensing chromosomes, and as the chromosomes congress a bipolar metaphase I spindle is established, with chromosomes correctly aligned at the metaphase plate. Meiotic spindle migration occurs after its formation and this process relies on a dynamic microfilament meshwork (Azoury et al., 2008), actin filament nucleator Formin-2 (Dumont et al, 2007) and RhoGTPase ( $\mathrm{Na}$ and Zernicka-Goetz, 2006). The peripheral spindle migration is a crucial process that assures conservation of ooplasm through asymmetrical cell division of the polar body.

AMPK is a heterotrimeric protein that contains an a catalytic subunit and $\beta$ and $\gamma$ regulatory subunits. It regulates the cellular energy level by sensing the ratio of AMP-to-ATP and responds to low ATP levels by shutting down the energy consuming pathways and upregulating ATP production. It is activated via phosphorylation by upstream kinases of threonine 172 on the catalytic a subunit (Hardie, 2003; Carling, 2004). Our lab has previously demonstrated a role for AMPK in the resumption of meiosis in mouse oocytes by showing that its activation by a variety of means induces GVB and that meiosis can be blocked by its inhibition (Chen et al, 2006; Downs and Chen, 2006; LaRosa and Downs, 2006, 2007; Chen and Downs, 2008). Further, AMPK not only has a role in GVB, but participates throughout the

Zygote, Vol. 22, No. 1 (February 2014): pg. 91-102. DOI. This article is (C) Cambridge University Press and permission has been granted for this version to appear in e-Publications@Marquette. Cambridge University Press does not grant permission for this article to be further copied/distributed or hosted elsewhere without the express permission from Cambridge University Press. 
entire maturation period, associating with chromosomes and the meiotic spindle and exerting positive and negative effects, respectively, on polar body formation and activation (Downs et al, 2010).

The meiotic spindle association of AMPK is intriguing, because numerous proteins showing a similar localization pattern are known to regulate meiotic spindle assembly and function; AMPK has also been shown to have a role in maintenance of genome integrity and establishment of cell polarity in Drosophila embryos and other somatic cells (see Discussion). So it was of interest to test how microtubule and spindle integrity was related to AMPK function in mouse oocytes. Our data indicate that active AMPK colocalization with $\gamma$-tubulin at microtubule organization centers (MTOC) during metaphase I and II is dependent on spindle integrity. Moreover, microtubule perturbants altered active AMPK localization and blocked AMPK-and hormoneinduced meiotic resumption. However, treatment of oocytes with AMPK inhibitor did not prevent spindle formation, despite suppressing the completion of meiotic maturation.

\section{Results}

\section{Immunofluorescent Staining of Active AMPK}

Oocytes undergoing in-vivo maturation after human chorionic gonadotropin (hCG) injection were fixed at different stages. The active AMPK was detected by using antibody against phosphothreonine 172 on the alpha catalytic subunit of AMPK. FITC-conjugated mouse anti-atubulin antibody was used to stain the spindle. Again, we confirmed that active AMPK localized at spindle poles during MI and MII. In addition, there was trace amount of active AMPK localized with chromosomes at the metaphase plate. Active AMPK localized at the spindle midzone during anaphase (Fig. 1). To test if AMPK is localized at microtubule organizing centers, anti- $\gamma$-tubulin antibody was used to stain MTOC. Double immunoflorescent staining showed that active AMPK colocalized with $\mathrm{Y}$-tubulin during MI and MII; however, during anaphase, $\gamma$-tubulin localized along the microtubule spindle and no punctate staining of $\mathrm{Y}$-tubulin at spindle poles was detected (Fig. 2).

Zygote, Vol. 22, No. 1 (February 2014): pg. 91-102. DOI. This article is (C) Cambridge University Press and permission has been granted for this version to appear in e-Publications@Marquette. Cambridge University Press does not grant permission for this article to be further copied/distributed or hosted elsewhere without the express permission from Cambridge University Press. 
NOT THE PUBLISHED VERSION; this is the author's final, peer-reviewed manuscript. The published version may be accessed by following the link in the citation at the bottom of the page.

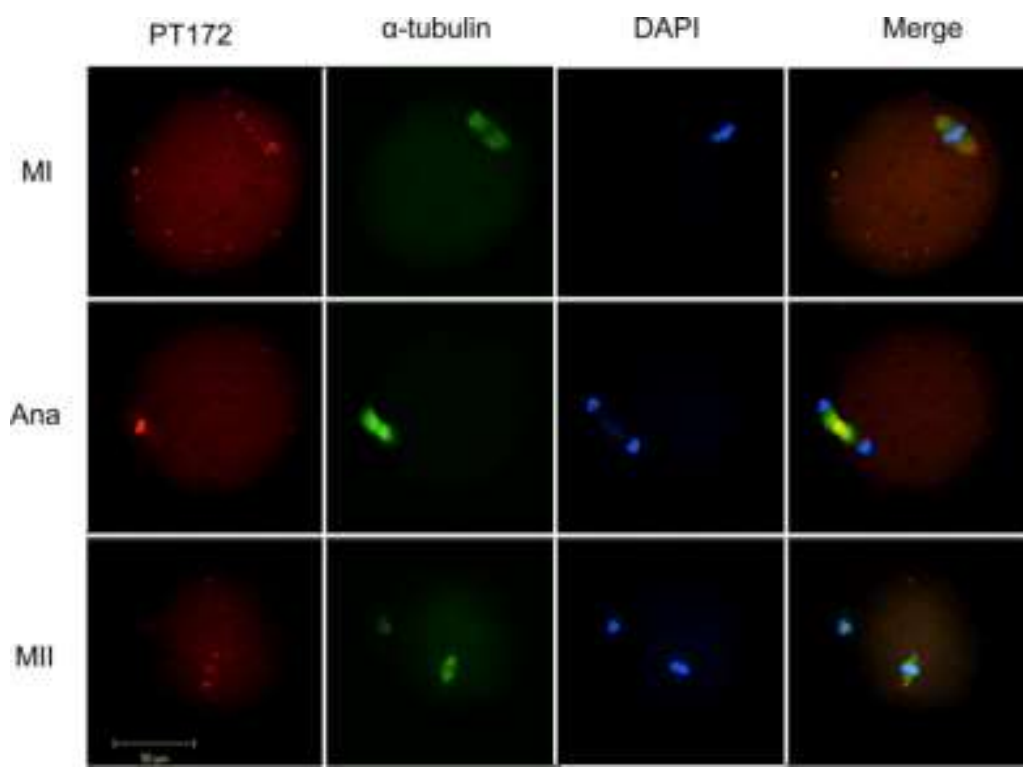

Figure 1 Immunofluorescent staining of active AMPK and a-tubulin. Oocytes were collected 8, 10 and $16 \mathrm{~h}$ after administration of hCG to PMSG-primed mice to obtain maturation stages of MI, anaphase (Ana) and MII, respectively. Active AMPK localized at the spindle poles at the MI and MII stages, but localized at the midzone of the spindle during anaphase. Red, active AMPK; green, a - tubulin; blue, chromatin. The yellow scale bar represents $50 \mu \mathrm{m}$.

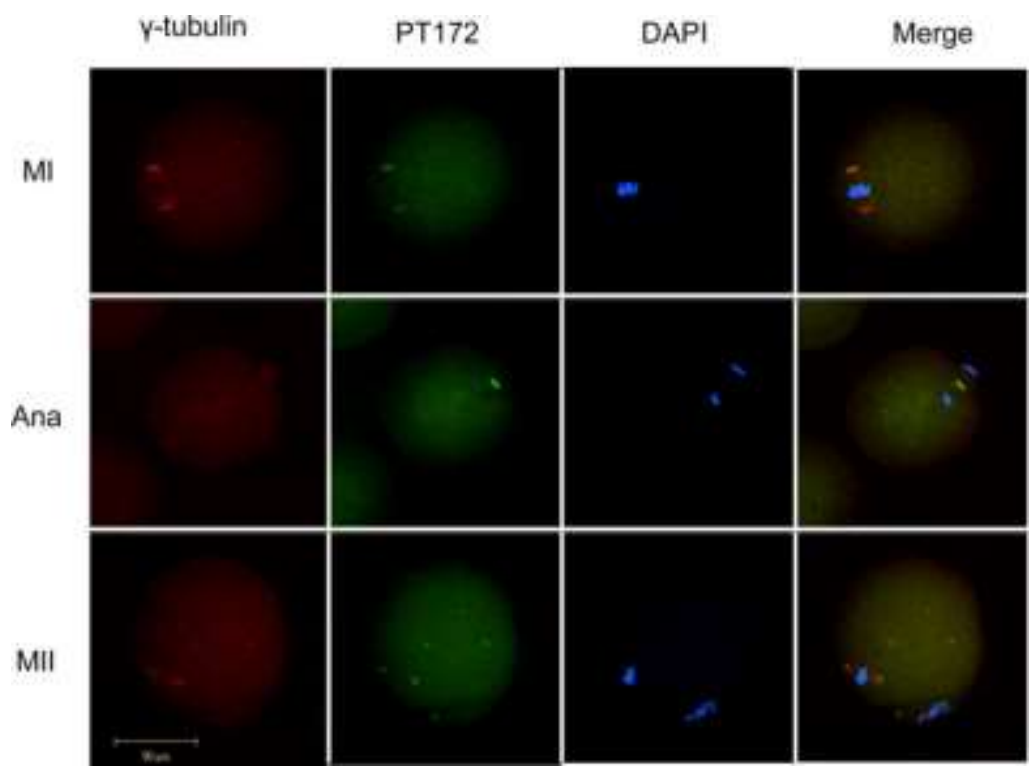

Figure 2 Immunoflurescent staining of active AMPK and $y$-tubulin in oocytes from mice induced to mature with hCG. Red, $\mathrm{y}$-tubulin; green, active AMPK; blue, chromatin. Active AMPK colocalized with $y$-tubulin at spindle organizing centers at both MI and MII stages. The yellow scale bar indicates $50 \mu \mathrm{m}$.

Zygote, Vol. 22, No. 1 (February 2014): pg. 91-102. DOI. This article is @ Cambridge University Press and permission has been granted for this version to appear in e-Publications@Marquette. Cambridge University Press does not grant permission for this article to be further copied/distributed or hosted elsewhere without the express permission from Cambridge University Press. 


\section{Effect of Disturbing Microtubule Integrity on Active AMPK Localization}

To test if active AMPK localization is dependent on spindle microtubule integrity, microtubule-targeted agents were tested on cumulus cell-enclosed oocytes (CEO) during in vitro culture. Isolated CEOs were arrested in $300 \mu \mathrm{M}$ dibutyryl cAMP (dbcAMP) and then treated with $0.1 \mu \mathrm{g} / \mathrm{ml} \mathrm{FSH}$ to induce maturation. CEOs were cultured for $17 \mathrm{~h}$ before addition of the microtubule-depolymerization agent, nocodazole $(0.05 \mu \mathrm{g} / \mathrm{ml})$, or the microtubule-stabilizing agent, paclitaxel $(20 \mu \mathrm{M})$, and oocytes were fixed $1 \mathrm{~h}$ later. Nocodazole significantly depolymerized the spindle, and as a result, chromosomes became scattered and normal spindle pole localization of active AMPK was disrupted (Fig. 3A, top). When oocytes were treated with paclitaxel, microtubules were excessively polymerized and spindles were larger than normal; formation of a double meiotic spindle was occasionally observed, with 2 points of active AMPK localization at each pole. Many small asters also appeared in the cytoplasm with colocalized AMPK (Fig. 3A, bottom). It is well documented that the effect of nocodazole on spindle destabilization is reversible. To test whether reestablishment of a bipolar spindle could bring active AMPK localization back to its normal localization, in-vitro matured MII-stage CEOs were subjected to high dose of nocodazole treatment $(5 \mu \mathrm{g} / \mathrm{ml})$ for 10 minutes; the nocodazole was then washed out and oocytes were allowed to recover for $1 \mathrm{~h}$ to allow reformation of bipolar MII spindle before fixation and processing for immunoflorescent staining. The MII spindle completely disappeared after 10 min treatment with nocodazole and the localization of active AMPK was randomly dispersed (data not shown). Upon spindle repolymerization, active AMPK localization returned to the spindle poles (Fig 3B) thereby demonstrating reversibility of the nocodazole effect and a microtubuledependent localization of active AMPK in mouse oocytes.

Zygote, Vol. 22, No. 1 (February 2014): pg. 91-102. DOI. This article is (C) Cambridge University Press and permission has been granted for this version to appear in e-Publications@Marquette. Cambridge University Press does not grant permission for this article to be further copied/distributed or hosted elsewhere without the express permission from Cambridge University Press. 
NOT THE PUBLISHED VERSION; this is the author's final, peer-reviewed manuscript. The published version may be accessed by following the link in the citation at the bottom of the page.

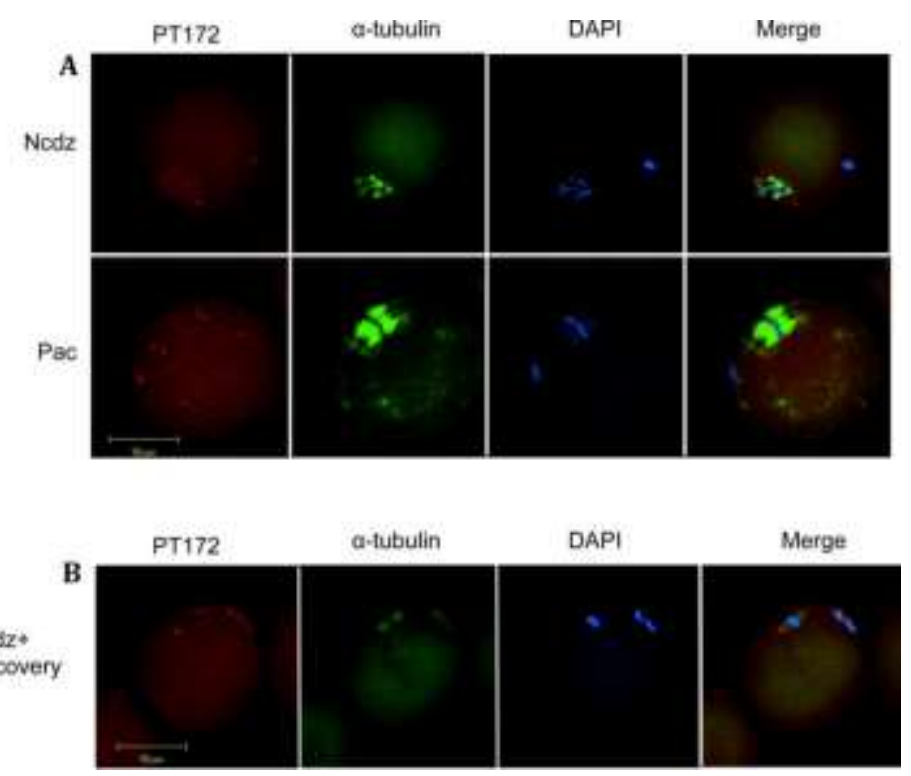

Figure 3 Effect of microtubule-targeted agents on active AMPK localization. (A) CEO were cultured in the presence of FSH plus $300 \mu \mathrm{M}$ dbcAMP for $17 \mathrm{~h}$; then either the microtubule-destabilizing agent, nocodazole $(0.05 \mu \mathrm{g} / \mathrm{ml}$; top $)$, or microtubulestabilizing agent, paclitaxel $(20 \mu \mathrm{M}$; bottom), was added and oocytes were fixed $1 \mathrm{~h}$ later and processed for immunostaining for active AMPK (PT172) and a-tubulin. Nocodazole treatment disrupted the normal spindle pole localization of active AMPK. When treated with paclitaxel, microtubules were excessively polymerized, and this was associated with increased AMPK staining. (B) Reversibility of nocodozole action. After CEO were cultured $17 \mathrm{~h}$ in the presence of FSH plus $300 \mu \mathrm{M}$ dbcAMP, oocytes were exposed to nocodazole $(5 \mu \mathrm{g} / \mathrm{ml})$ for $10 \mathrm{~min}$. The nocodazole was then washed out and oocytes were allowed to recover for $1 \mathrm{~h}$ before fixation and immunostaining. Upon microtubule repolymerization, active AMPK reestablished its normal spindle pole localization. Red, active AMPK; green, a -tubulin; blue, chromatin. Scale bar, $50 \mu \mathrm{m}$.

\section{Effect of Cytoskeletal Disrupting Agents on Maturation and AMPK Activity}

We have shown that AMPK is involved in hormone-induced maturation and its activation precedes GVB in mouse oocytes (Chen and Downs, 2008). Results from the current study indicate that AMPK involvement depends on microtubule integrity. We therefore tested whether perturbing microtubule integrity would abolish AMPK activity and inhibit meiotic induction. The effects of microtubule-targeted agents were tested on meiotic induction and AMPK activity. dbcAMParrested CEOs were treated with $0.1 \mu \mathrm{g} / \mathrm{ml} \mathrm{FSH}$ to induce meiotic resumption, exposed to increasing concentrations of nocodazole, and assessed for GVB after 17-18h. As shown in Fig. 4A, FSH increased

Zygote, Vol. 22, No. 1 (February 2014): pg. 91-102. DOI. This article is (C Cambridge University Press and permission has been granted for this version to appear in e-Publications@Marquette. Cambridge University Press does not grant permission for this article to be further copied/distributed or hosted elsewhere without the express permission from Cambridge University Press. 
the percentage of GVB by $62 \%$, while supplementation with nocodazole significantly blocked this increase in a dose-dependent manner, by $62 \%$ at the highest dose tested. DMSO alone, the nocodazole vehicle, had no effect on meiotic resumption (data not presented). To test for a direct effect of nocodazole on the oocyte, dbcAMP-arrested DOs were treated with $250 \mu \mathrm{M}$ AICAR, an AMPK activator, and scored for GVB. AICAR stimulated an increase in GVB from $23 \%$ to $89 \%$. This stimulation was abolished by nocodazole (GVB reduced to $8 \%$ ), which was even lower than the dbcAMP control (Fig 4B). This inhibition was completely reversible, thereby demonstrating that the drug did not act through toxic means.
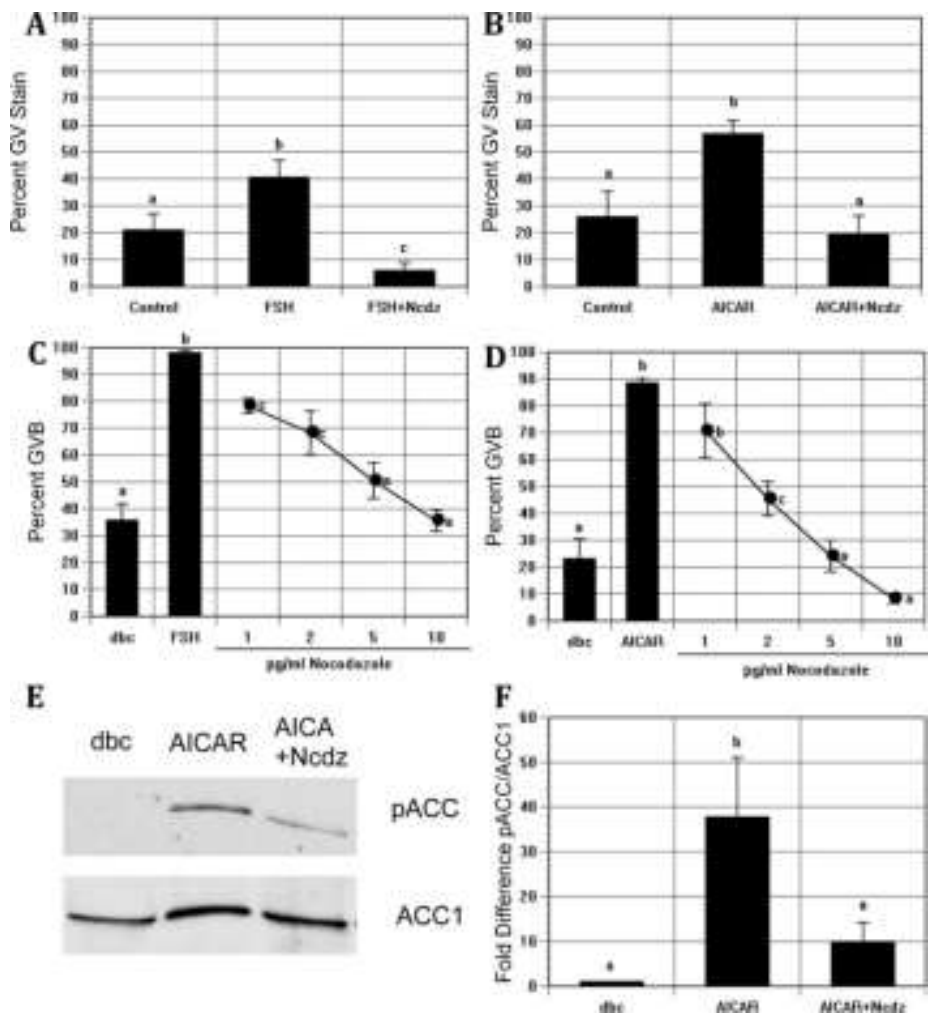

Figure 4 Nocodazole treatment blocked germinal vesicle staining of active AMPK prior to meiotic resumption. (A) CEO were cultured in $300 \mu \mathrm{M}$ dbcAMP alone (control) or dbcAMP(dbc) plus FSH with or without $10 \mu \mathrm{g} / \mathrm{ml}$ nocodazole. 4h later oocytes were fixed and processed for PT172 staining. Percentage of oocytes showing active AMPK GV stain was assessed under confocal microscopy. (B) DO were cultured for $2.5 \mathrm{~h}$ in the same medium as CEO but FSH was substituted with $250 \mu \mathrm{M}$ AICAR. Nocodazole reduced the GV stain to the negative control level. (C) CEO were cultured in the medium containing FSH plus $300 \mu \mathrm{M}$ dbcAMP in the presence of various concentration of nocodazole. Germinal vesicle breakdown (GVB) was assessed 17-18h later. (D) DO were cultured in the medium with $250 \mu \mathrm{M}$ AICAR plus $300 \mu \mathrm{M}$ dbcAMP and treated with 
NOT THE PUBLISHED VERSION; this is the author's final, peer-reviewed manuscript. The published version may be accessed by following the link in the citation at the bottom of the page.

different doses of nocodazole. Percentage of GVB was assessed $4 \mathrm{~h}$ after culture. (E) Western blot analysis of PACC of oocytes that were treated as described in figure 4B, ACC1 was used as loading control. (F) Quantification of pACC and ACC1 from western blot. pACC and ACC1 ratio were normalized to control dbcAMP-treated group.

As previously reported, FSH and AICAR increased phosphoAMPK staining in the germinal vesicle prior to GVB. This staining pattern is characterized by homogeneous staining throughout the germinal vesicle with absence of label within nucleoli (Chen and Downs, 2008). Since nocodazole blocked AICAR- and FSH-induced GVB, we determined if this GV staining pattern was present after nocodazole treatment. FSH-treated CEOs were cultured for $4 \mathrm{~h}$ and AICAR-treated DOs were cultured for $2.5 \mathrm{~h}$ before fixation and immunofluorescent staining. As shown in Figure 4C, FSH increased the frequency of nuclear staining from $21 \%$ to $41 \%$, and this increase was eliminated by exposure to nocodazole. A similar pattern was evident in DO, as AICAR increased GV staining from $26 \%$ to $57 \%$, an action prevented by nocodazole (only 6\% nuclear staining; Fig. 4D). These data support the idea that activity of AMPK is greatly influenced by microtubule integrity. This was confirmed by western blot analysis of nocodazole-treated oocytes that showed suppression of AICAR-induced AMPK activity, using phospho-acetyl CoA carboxylase as a marker for AMPK activity (Fig 4E, 4F4F).

When CEOs were treated with another microtubule-destabilizing agent, vinblastine, meiotic induction was again suppressed, with a $31 \%$ decrease at the highest concentration tested (Fig 5A). Inhibition was even more robust in AICAR-treated DOs, with $20 \mu \mathrm{g} / \mathrm{ml}$ vinblastine reducing the maturation percentage to control levels (Fig $5 \mathrm{~B}$ ). 

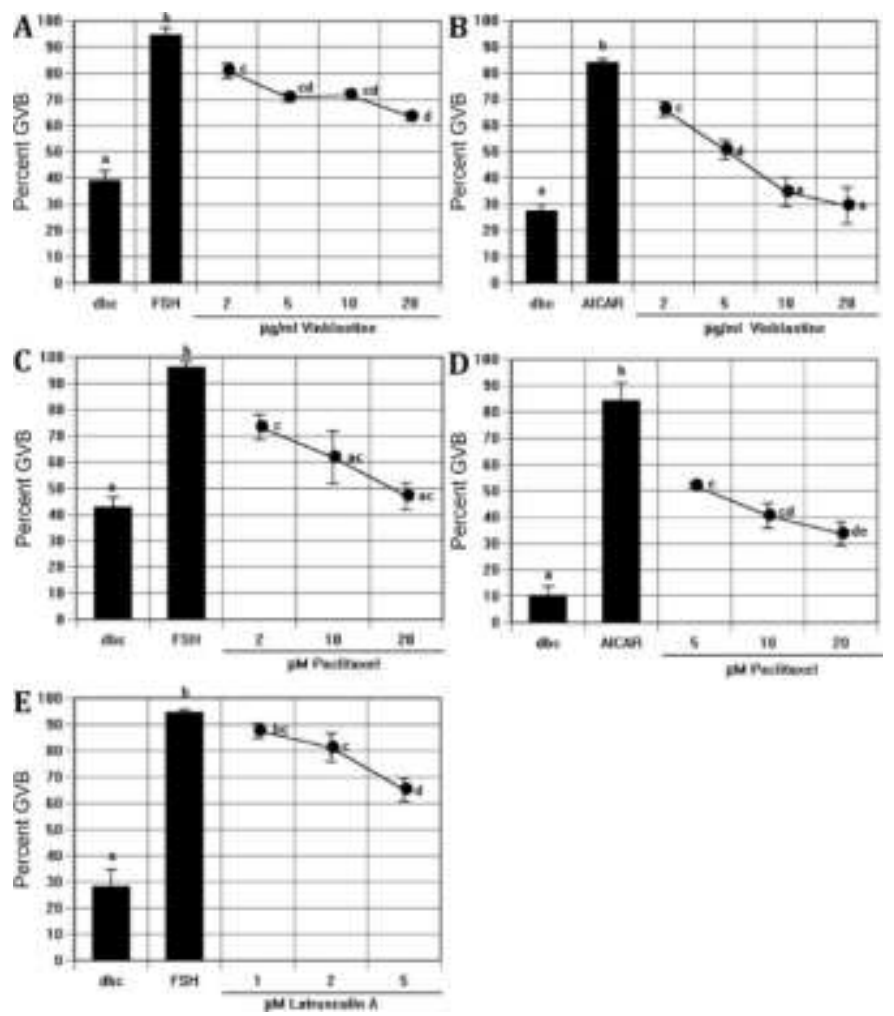

Figure 5 Effects of other microtubule-targeted agents on FSH-and AICAR-induced maturation in vitro. (A) and (C) CEO were cultured in the medium containing FSH plus $300 \mu \mathrm{M}$ dbcAMP ( $\mathrm{dbc}$ ) in the presence of various concentration of vinblastine and paclitaxel respectively. (B) and (D) DO were cultured in the medium with $250 \mu \mathrm{M}$ AICAR plus $300 \mu \mathrm{M}$ dbcAMP and treated with different doses of vinblastine and paclitaxel. CEO were cultured for $17 \mathrm{~h}$ and DO were cultured for $4 \mathrm{~h}$ before percentage of GVB was assessed. (E) Effect of an actin-depolymerizing agent, latrunctulin A, on meiotic resumption of DO.

To test how stabilizing microtubules affects meiotic induction, the microtubule-stabilizing agent, paclitaxel was utilized. CEOs were cultured 17-18h and treated with FSH plus increasing doses of paclitaxel. Similar to the finding with microtubule disrupting agents, FSH-induced GVB was blocked in dose-dependent fashion by paclitaxel (Fig 5C), and the agent was even more potent in AICAR-treated DO (Fig 5D). When FSH- and paclitaxel-treated oocytes were fixed after $4 \mathrm{~h}$ and stained with anti-PT172 antibody, no label was observed in the $\mathrm{GV}$; however, punctate staining was present throughout the cytoplasm (data not shown). When paclitaxel was added to AICAR-treated DOs, punctate staining of active AMPK was observed near or within the GV, but with no homogeneous staining within the GV. The increased

Zygote, Vol. 22, No. 1 (February 2014): pg. 91-102. DOI. This article is @ Cambridge University Press and permission has been granted for this version to appear in e-Publications@Marquette. Cambridge University Press does not grant permission for this article to be further copied/distributed or hosted elsewhere without the express permission from Cambridge University Press. 
punctate staining of active AMPK after paclitaxel treatment may correspond to excessive stabilization of microtubule polymers.

To determine whether inhibiting actin filament polymerization plays a role in meiotic induction, cytochalasin D or latrunculin A were added to either FSH-stimulated CEO cultures or AICAR-stimulated DO cultures. There was no effect of cytochalasin D on GVB; latrunculin A treatment led to a modest reduction (29\%) of GVB in FSH-treated CEO (Fig. 5E), but it was toxic to AICAR-treated DO.

\section{Effect of AMPK Modulators on Cytoskeleton Dynamics}

Our data suggest microtubule integrity regulates localization and activity of AMPK. We next tested if the reverse regulation was true; that is, if AMPK regulates spindle dynamics. AMPK stimulators, AICAR, AMP and 8-Br-adenosine accelerate PB formation of spontaneously maturing $\mathrm{CEO}_{\mathrm{s}}$ (Downs et al., 2010), and it is possible that this is mediated by accelerated spindle formation. First, $\mathrm{CEO}_{\mathrm{s}}$ were matured spontaneously in MEM/BSA control medium in the presence or absence of $200 \mu \mathrm{M}$ AICAR and the kinetics of GVB were determined. After 45 minutes of AICAR treatment, the percentage of GVB was increased from of $35 \%$ to $52 \%$; thereafter, maturation percentages were comparable up to 105 min of culture (Fig. 6A). To examine the impact of AICAR on spindle formation, CEOs that were cultured in the presence or absence of AICAR were fixed at discrete time points and processed for alpha-tubulin immunofluorescent staining.

Polymerization of microtubules into a barrel-shaped spindle was the criterion used for assessment. AICAR significantly increased spindle formation at the early time point (an increase from $12 \%$ to $24 \%$ at $3 \mathrm{~h}$ ), which is roughly 1 hour after GVB (Fig. 6B). A trend toward increased spindle formation in AICAR-treated oocytes continued for the next $2 \mathrm{~h}$, but differences were not significant.

Zygote, Vol. 22, No. 1 (February 2014): pg. 91-102. DOI. This article is (C) Cambridge University Press and permission has been granted for this version to appear in e-Publications@Marquette. Cambridge University Press does not grant permission for this article to be further copied/distributed or hosted elsewhere without the express permission from Cambridge University Press. 
NOT THE PUBLISHED VERSION; this is the author's final, peer-reviewed manuscript. The published version may be accessed by following the link in the citation at the bottom of the page.
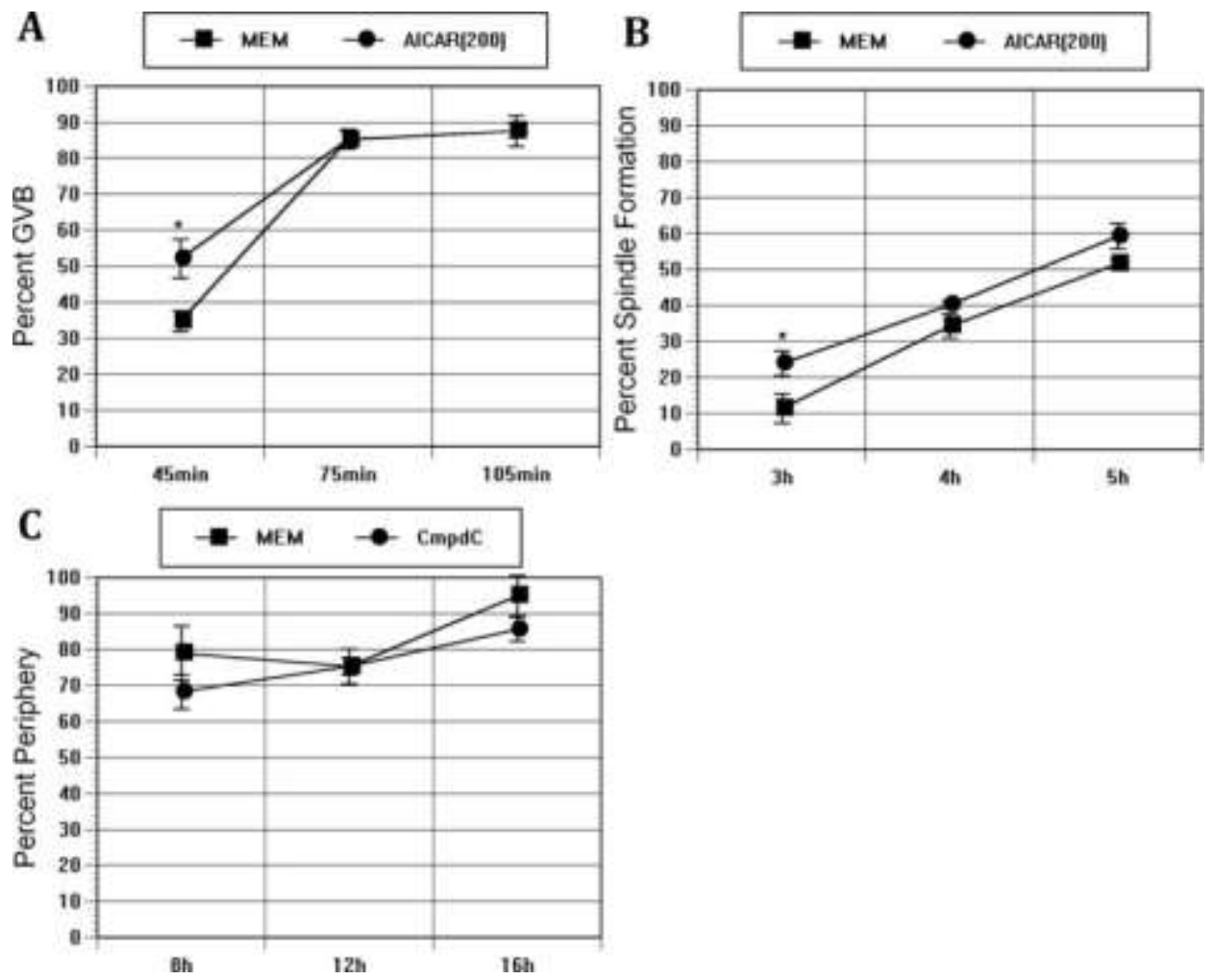

Figure 6 (A) Effect of AMPK activator, AICAR, on spontaneous maturation. CEO were cultured in the control MEM or medium supplemented with $200 \mu \mathrm{M}$ AICAR, percentage of GVB was checked at 45,75 and 105min after initiation of the culture. (B) Effect of AICAR on early spindle formation. CEO were cultured in MEM or MEM plus 200 $\mu \mathrm{M}$ AICAR for 3,4, and $5 \mathrm{~h}$ before spindle formation was assessed by immunofluorescent staining. (C) Effect of AMPK inhibitor, Compound C, on spindle periphery movement. CEO were cultured in control medium or medium containing $2.5 \mu \mathrm{M}$ Compound $\mathrm{C}$. Kinetics of spindle periphery movement was examined at indicated time points. Asterisks indicate significant differences between two parallel groups.

Spindle migration is important for asymmetric cell division in oocytes, which helps minimize loss of cytoplasm during polar body extrusion. We determined whether blocking AMPK activity could influence the migration of the meiotic spindle. Spontaneously maturing CEOs were supplemented with the AMPK inhibitor, Compound C, and position of the spindle was checked at 8,12 and $16 \mathrm{~h}$ after initiation of culture. Spindles were considered to have migrated to the periphery if they were located more than one-half the radius of the oocyte from its center. As shown in Figure $6 \mathrm{C}$, by 8 h culture $79 \%$ of the control oocytes had a peripherally located spindle; this number was $68 \%$ in Compound C-treated oocytes, which was not significantly different

Zygote, Vol. 22, No. 1 (February 2014): pg. 91-102. DOI. This article is (C Cambridge University Press and permission has been granted for this version to appear in e-Publications@Marquette. Cambridge University Press does not grant permission for this article to be further copied/distributed or hosted elsewhere without the express permission from Cambridge University Press. 
from controls. By $16 \mathrm{~h}$, most CEOs in control medium had released the first polar body and $95 \%$ of the oocyte spindles were peripherally localized. The supplementation of Compound C significantly blocked PB formation, but did not interfere with the peripheral movement of the spindle.

Finally, we tested whether inhibition of AMPK activity would perturb actin microfilament dynamics, especially the polymerization status of the cortical region. Extensive actin polymerization occurs in the cortical area and facilitates attachment of the outer-most spindle pole to the cortex (Azoury et al., 2008). When CEOs were cultured for $9.5 \mathrm{~h}$ or $11.5 \mathrm{~h}$ in control MEM or medium containing $2.5 \mu \mathrm{M}$ Compound $\mathrm{C}$ and processed for phalloidin staining, normal $\mathrm{F}$ actin polymerization was observed in both groups (data not shown). Thus, Compound $\mathrm{C}$ treatment did not interfere with polar body formation by blocking actin microfilament polymerization.

\section{DISCUSSION}

In this study, we show that active AMPK localizes in mouse oocytes at the meiotic spindle pole with $y$-tubulin during metaphase I and II and at the spindle midzone during anaphase and that this localization pattern is reversibly abolished by nocodazole treatment. Incubation with paclitaxel induced excessive punctate staining of pAMPK associated with small asters in the cytoplasm. Disturbing microtubule integrity not only affected the localization of PT172, but also its activity, suppressing hormone- and AICAR-induced meiotic resumption and GV labeling of active AMPK prior to GVB. Disrupting actin polymerization with latrunculin $A$, but not cytochalasin $D$, had only a modest inhibitory effect on meiotic resumption. On the other hand, AMPK stimulation accelerated both GVB and spindle formation, while blocking its activity with compound $\mathrm{C}$ did not interfere with peripheral spindle migration, though karyokinesis was suppressed.

In a previous study (Downs et al., 2010), we demonstrated that active AMPK associates with chromosomes after GVB, localizes to the spindle pole during Metaphase I and II, and moves to the spindle midzone during anaphase. This localization pattern was identical whether maturation was induced in vitro by FSH or AICAR, in vivo by hCG injection, or occurred via spontaneous maturation in vitro. Here

Zygote, Vol. 22, No. 1 (February 2014): pg. 91-102. DOI. This article is @ Cambridge University Press and permission has been granted for this version to appear in e-Publications@Marquette. Cambridge University Press does not grant permission for this article to be further copied/distributed or hosted elsewhere without the express permission from Cambridge University Press. 
we show that active AMPK colocalizes with $y$-tubulin, indicating an association with spindle organizing centers during formation of both metaphase I and II spindles. This distribution pattern of pAMPK during oocyte maturation is similar to that occurring during mitosis of somatic cells (Vazquez-Martin et al., 2009) and is consistent with a reported role for AMPK in cell cycle progression (Bettencourt-Dias et al, 2004; Alessi et al, 2006; Koh and Chung, 2007; Williams and Brenman, 2008). Indeed, previous work from this lab has demonstrated that AMPK not only induces meiotic resumption in mouse oocytes (Chen et al, 2006; Chen and Downs, 2008) but also promotes the completion of maturation and prevents premature activation (Downs et al, 2010).

The changes of AMPK localization throughout maturation suggest a dynamic cellular transport process at work. The poleward transport of active AMPK might be dependent on the minus-end directed motor protein, dynein, which has been shown to be critical for spindle pole transport of proteins such as NuMA and Eg5 (Merdes et al, 2000; Uteng et al, 2008). While the majority of staining at metaphase was at the spindle poles, there was still detectable labeling at the chromosomes. It is possible that AMPK interacts with chromosomes or associated checkpoint proteins that regulate cell cycle progression. However, we cannot discount the possibilities of incomplete transport of the kinase to the spindle pole or early translocation to the midzone, the latter occurring during anaphase.

Microtubule disrupting agents dramatically affected the localization of AMPK within the oocyte. Exposure to nocodazole destroyed the spindle structure and led to dispersal of active AMPK in a punctate staining pattern that coincided with staining of microtubule asters, indicating that the localization pattern of active AMPK is dependent on the integrity of the meiotic spindle and presence of MTOCs. Mouse oocytes have multiple acentriolar MTOCs that can be grouped into two subsets: one is associated with the meiotic spindle and the other is cortical (Maro et al, 1985; Schatten et al, 1986; Messinger and Albertini, 1991). It is possible that active AMPK is more concentrated around MTOCs with nucleating capacity, since stabilization of microtubules with paclitaxel treatment induced further accumulation of AMPK at MTOCs and enlarged spindles. 
Data herein indicate that AMPK control of meiotic resumption is also influenced by microtubule assembly dynamics. Disruption of microtubules with nocodazole and vinblastine, as well as their stabilization with paclitaxel, blocked both AICAR-induced maturation in $\mathrm{DO}$ and $\mathrm{FSH}$-induced maturation in CEO. This was associated with suppression of AMPK activation, as determined by Western blotting as well as loss of pAMPK staining in the germinal vesicle that occurs prior to meiotic resumption (cf, Chen and Downs, 2008).

Compartmentalization of different cellular components is a crucial mechanism for controlling function in discrete micro-environments and influences cell cycle regulation (Pines, 1999). For instance, Cdc25B adopts nuclear localization shortly before GVB, where it regulates MPF activity (Oh et al, 2010), and mitogen-activated protein kinase (MAPK) translocates to the germinal vesicle just before GVB in pig oocytes (Inoue et al., 1998). Nocodazole- and paclitaxel-suppressed GV staining of pAMPK in FSH- and AICAR-treated oocytes, coincident with a reduction in meiotic resumption, suggests a microtubule-dependent step in AMPK regulation of meiosis that involves nuclear localization. Nuclear transport is mediated by nuclear pore complexes that span the nuclear membrane and facilitate the exchange of proteins between the cytoplasm and nucleoplasm (Liu and Liu, 2007; Stewart, 2007). In some instances, successful nuclear import requires the active participation of the cytoskeleton (Wagstaff and Jans, 2009; Salman et al, 2010). This has been demonstrated for p53 (Rathinasamy and Panda, 2008; Giannakakou et al, 2000) and parathyroid hormonerelated protein (Lam et al, 2002), where mictrotubule-dependent transport of protein to the nucleus has been implicated. It is reasonable to propose that a similar mechanism exists in mouse oocytes-ie, that microtubules aid in the meiotic induction process by facilitating accumulation of AMPK at the nucleus periphery where it is then imported by conventional means. Alternatively, we cannot discount the possibility that disrupting microtubule dynamics interferes with meiotic maturation by perturbing the spatial organization of signaling pathway components other than, or in addition to, AMPK that help drive meiotic resumption in response to FSH and AICAR.

Nocodazole was shown to block GVB in spontaneously maturing rat oocytes (Albertini, 1987), but we did not observe a similar inhibitory action on spontaneously maturing mouse oocytes (data not shown), results consistent with those of Van Blerkom and Bell (1986).

Zygote, Vol. 22, No. 1 (February 2014): pg. 91-102. DOI. This article is (C Cambridge University Press and permission has been granted for this version to appear in e-Publications@Marquette. Cambridge University Press does not grant permission for this article to be further copied/distributed or hosted elsewhere without the express permission from Cambridge University Press. 
Interestingly, Rime and Ozon (1988) suppressed GVB in mouse oocytes with estramustine, an anti-mitotic compound that can block microtubule polymerization through its intereaction with microtubuleassociated proteins.

Supplementation with taxol also did not affect the GVB of spontaneously maturing mouse oocytes (data not shown) and this has been shown by others for both rat and mouse oocytes; however, like the effects with nocodazole, taxol impairs later meiotic progression, resulting in failure of karyokinesis in mouse oocytes (Albertini, 1987; Combelles and Albertini, 2001). These effects of microtubule perturbants imply differences between the two species regarding meiotic regulation. In addition, our results indicate that in vitro meiotic induction of mouse oocytes is more susceptible to microtubule disturbance than spontaneously maturing oocytes and provide further evidence that these two types of maturation are regulated differently.

In many cells, AMPK is regulated by LKB1 through phosphorylation of the threonine 172 activation site on the alpha subunit (Dario et al, 2006). LKB1 is a tumor suppressor that has been implicated in establishing cell polarity through its involvement in AMPK activation (Alessi et al, 2006; Williams and Brenman, 2008; Jansen et al, 2009). For example, loss of LKB1 led to polarity defects in lung cancer cells (Zhang et al., 2008) and epithelial cells (Mirouse et al, 2007), neuroblasts (Bonaccorsi et al, 2007) and developing embryos (Lee et al, 2007) of Drosophila. Moreover, Szczepańska and Maleszewski (2005) reported that LKB1 associates with the meiotic spindle in mouse oocytes and proposed that it has a role in oocyte polarity; thus, it was of interest to test whether AMPK is also involved in a similar capacity in mouse oocytes. In oocytes, the spindle forms at the center of the oocyte after GVB, and then migrates toward the oocyte periphery where the PB is extruded, a process crucial to asymmetric cell division and differentiation of cortex into a cortical granule-free domain (Sun and Schatten, 2006).

Inhibiting AMPK activity in spontaneously maturing CEOs with Compound $\mathrm{C}$ did not perturb the peripheral movement of the spindle. Though some recent studies also suggest the participation of microtubules ( $\mathrm{Ai}$ et al, 2009), spindle movement in the oocyte is known to be highly dependent on a dense actin microfilament

Zygote, Vol. 22, No. 1 (February 2014): pg. 91-102. DOI. This article is (C) Cambridge University Press and permission has been granted for this version to appear in e-Publications@Marquette. Cambridge University Press does not grant permission for this article to be further copied/distributed or hosted elsewhere without the express permission from Cambridge University Press. 
meshwork (Azoury et al, 2008). Our results suggest that interfering with AMPK activity does not affect the integrity of the cortical actin network, because the extensive $\mathrm{F}$ actin polymerization in the cortex near the spindle appeared unperturbed by compound $C$ treatment. Myosin regulatory light chain (MLC) is an important component of myosin II that participates in actomyosin-mediated cytokinesis at the cleavage furrow (Dumont et al., 2007) and becomes phosphorylated in somatic cells in response to AMPK activation (Lee et al., 2007). However, it is unclear whether MLC is a physiological substrate for AMPK under energy depleted conditions (Bultot et al., 2009). It will be interesting to determine if AMPK influences the interaction of actin and myosin at the time of cytokinesis.

Acceleration of the kinetics of polar body extrusion by AMPKstimulating agents (Downs et al., 2010) indicates an active role for AMPK throughout the entire maturation process, and this might be accomplished by action on earlier meiotic events. Indeed, we show herein that the rate of GVB and spindle formation is increased by AICAR treatment. These data indicate that AMPK manifests an early effect during maturation that shortens the time required to complete maturation. In support of this, the increase in polar body formation is eliminated when AICAR treatment is delayed, while delaying compound $\mathrm{C}$ treatment decreases its inhibitory action (Downs et al, 2010).

The close association of AMPK with microtubules suggests a functional role with the meiotic apparatus. In mouse oocytes, numerous proteins exhibit a similar localization pattern and have important roles in spindle organization and function. For instance, aurora-A kinase induces GVB in Xenopus oocyte and has to be dephosphorylated for the MI-MII transition (Ma et al., 2003). Aurora-A is critical for spindle assembly, centrosome maturation and chromosome segregation. Furthermore, its role is not limited to oocyte maturation, as it is also involved in early embryo spindle organization (Yao et al, 2004; Ding et al., 2011). Another aurora kinase family member, Aurora- $B$, is one of the chromosome passenger proteins and specifically localizes to the metaphase chromosomes, where it mediates chromosome segregation and spindle kinetochore attachment (Ruchaud et al, 2007; Uzbekova et al., 2008). Aurora C kinase localization is similar to that of active AMPK; moreover, 
injection of deficient kinase induced failure of meiosis I and disrupted proper localization of kinetochore proteins, BubR1 and Bub (Yang et al., 2010). Astrin is associated with meiotic spindle microtubules with particular concentration at the spindle poles, and perturbation of its function greatly compromises normal spindle integrity and chromosome segregation (Yuan et al, 2009). The apoptosis inhibitor protein, survivin, mimics AMPK localization in mouse oocytes and its depletion adversely affects chromosome alignment and alters normal polar body extrusion (Sun et al, 2009). Another similarly localized kinase, Polo-like kinase-1 (Plk1), was implicated in spindle assembly in oocytes and later mitosis in the embryo after fertilization (Wianny et al, 1998; Tong et al, 2002). In addition to regulating spindle organization, Plk1 also promotes $\mathrm{M}$ phase entry by participating in the MPF amplification loop (Karaiskou et al., 2004), and blocking its activity with antibody reduces the GVB rate (Tong et al, 2002). Of particular relevance to the present study is the recent finding that pharmacological inhibition of PIk1 blocks AMPK activation and cytokinesis in HeLa cells (Vazquez-Martin et al, 2011). Another kinase, protein kinase $\mathrm{C}$ delta (PKC $\delta$ ), associates with $\mathrm{y}$-tubulin and pericentrin, and disruption of its function leads to spindle disorganization and misalignment of chromosomes (Ma and Koch, 2008). PKC has also been shown to be involved in the MI-to-MII transition (Viveiros et al., 2001). Finally, phospho-MEK1/2, the upstream kinase for MAPK activation, displays a prominent presence at the spindle poles in mouse oocytes, and blocking MAPK leads to meiotic spindle abnormalities and poor chromatin condensation (Yu et al, 2007; Sun et al, 2008).

It may be that AMPK interacts with one or more of these proteins to influence meiotic progression. A less likely scenario is that the kinase docks at MTOCs without contributing to spindle assembly or function.

In summary, we have shown AMPK localization in the mouse oocyte to be coincident with $\gamma$-tubulin and dependent on microtubule integrity. In addition, both the induction of meiotic resumption and polar body extrusion are sensitive to microtubule perturbation. Thus, interaction of AMPK with microtubules appears essential for its regulatory function throughout the maturation period. 
NOT THE PUBLISHED VERSION; this is the author's final, peer-reviewed manuscript. The published version may be accessed by following the link in the citation at the bottom of the page.

\section{Materials and Methods}

\section{Oocyte Isolation and Culture Condition}

All procedures were approved by the Marquette University Institutional Animal Care and Use Committee. Immature, 19-23 day old $(\mathrm{C} 57 \mathrm{~B} / 6 \mathrm{~J} \times \mathrm{SJ} / \mathrm{J}) \mathrm{F}_{1}$ female mice were used for all experiments. Mice were primed with 5IU pregnant mare serum gonadotropin (PMSG) 2 days before the experiments. Mice were killed by cervical dislocation and ovaries were removed and placed in the petri dish containing culture medium. CEOs were isolated by puncturing the follicles with sterile needles. DOs were obtained by stripping cumulus cell by using mouth operated small-bore pipette. Both CEOs and DOs were washed twice and transferred to plastic culture tubes containing $1 \mathrm{ml}$ of the appropriate test medium. The culture medium used was Eagle minimum essential medium (Sigma, St Louis, MO) supplemented with penicillin, streptomycin sulfate, $0.23 \mathrm{mM}$ sodium pyruvate and $3 \mathrm{mg} / \mathrm{ml}$ bovine serum albumin (MP Biomedicals, Solon, $\mathrm{OH}$ ).

\section{Immunofluorescent Staining}

Oocytes were fixed with microtubule stabilizing buffer as previously described (Messinger and Albertini, 1991) at $4^{\circ} \mathrm{C}$ overnight. Oocytes were permeabilized 30 min with $0.1 \%$ triton-100 in blocking solution, which contained $10 \%$ donkey serum and $0.5 \mathrm{mg} / \mathrm{ml}$ saponin in PBS, followed by $1 \mathrm{~h}$ in blocking solution minus triton-100. Oocytes were incubated with primary antibody $(1: 100)$ overnight at $4^{\circ} \mathrm{C}$, and washed 4 times at room temperature in blocking buffer. Oocytes were coincubated with FITC-conjugated anti tubulin antibody $(1: 100)$ and Cy3-conjugated secondary antibody (1:100) $1 \mathrm{~h}$ at room temperature. After washing, oocytes were placed at slides and mounted with medium containing DAPI (Vector Laboratories, Burlingame, CA).

\section{Confocal Microscopy}

Oocytes were viewed on laser scanning confocal microscope (Carl Zeiss Co., Thornwood, NY) with a 63X objective. During scanning, all settings were kept constant: ie, laser power, detector gain, amplifier offset, amplifier gain, and pinhole size. Digitally

Zygote, Vol. 22, No. 1 (February 2014): pg. 91-102. DOI. This article is @ Cambridge University Press and permission has been granted for this version to appear in e-Publications@Marquette. Cambridge University Press does not grant permission for this article to be further copied/distributed or hosted elsewhere without the express permission from Cambridge University Press. 
NOT THE PUBLISHED VERSION; this is the author's final, peer-reviewed manuscript. The published version may be accessed by following the link in the citation at the bottom of the page.

recorded images were exported by LSM Examiner software (Carl Zeiss Co.).

\section{Western Blot Analysis}

Oocytes samples were washed with PBS/PVP, then twice with the protease inhibitor cocktail (Roche, Indianapolis, IN). Samples were treated with Laemmli's Buffer with $20 \%$ beta-mercaptoethanol at $95^{\circ} \mathrm{C}$ for 5 minutes. Electrophoresis was carried out using NuPAGE 3-8\% Tris-Acetate Gels (Invitrogen, Carlsbad, CA), and proteins were transferred to nitrocellulose. Membranes were blocked with 5\% non-fat milk, followed by incubation with primary antibody pACC $(1: 250$, Cell Signaling) at $4^{\circ} \mathrm{C}$ overnight. Blots were rinsed with TBS $(\mathrm{pH} \mathrm{7.4)}$ and TBS-Tween-20 (0.05\%), and incubated with HRP-conjugated goat anti-rabbit antibody (1:2000 in 5\% non-fat milk, Pierce) at room temperature for $60 \mathrm{~min}$. After washing, protein signals were detected by Super Signal West Pico Chemiluminescent Substrate (Pierce). Blots were stripped with Restore Western Blot Stripping Buffer (Thermo Scientific; Rockford, IL) and reprobed with anti-ACC1 antibody (1:250; Cell signaling) as a loading control. pACC/ACC1 ratio was quantified with Image] software based on protein band density.

\section{Chemicals}

Saponin, dbcAMP, donkey serum, nocodazole, and FITC-labeled mouse anti-alpha tubulin were purchased from Sigma-Aldrich Co. (St. Louis, MO). Cy3-conjugated donkey anti-rabbit antibody was supplied by Jackson ImmmoResearch (West Grove, PA). AICAR and Compound $C$ were obtained from Toronto Research Chemicals, Inc. (North York, Ontorio, Canada). Anti-phospho AMPK (PT172) antibody was purchased from Cell Signaling Technology (Beverly, MA). Highly purified ovine FSH was from the National Hormone and Peptide Program (NHPP) and Dr. A.F. Parlow.

\section{Statistical Analysis}

All experiments were repeated at least three times and data presented as mean \pm SEM. Percentages of GVB or nuclear stain underwent arcsin transformation and data were analyzed statistically

Zygote, Vol. 22, No. 1 (February 2014): pg. 91-102. DOI. This article is (C) Cambridge University Press and permission has been granted for this version to appear in e-Publications@Marquette. Cambridge University Press does not grant permission for this article to be further copied/distributed or hosted elsewhere without the express permission from Cambridge University Press. 
NOT THE PUBLISHED VERSION; this is the author's final, peer-reviewed manuscript. The published version may be accessed by following the link in the citation at the bottom of the page.

by ANOVA followed by Duncan's multiple range test. A $P$-value $<0.05$ was considered significant.

\section{References}

Ai JS, Li M, Schatten H, Sun QY. Regulatory mechanism of spindle movements during oocyte meiotic division. Asian-Aust J Anim Sci. 2009;22:14771486.

Albertini D. Cytoplasmic reorganization during the resumption of meiosis in cultured preovulatory rat oocytes. Dev Biol. 1987;120:121-131.

Alessi DR, Sakamoto K, Bayascas JR. LKB1-dependent signaling pathways. Ann Rev Biochem. 2006;75:137-163.

Azoury J, Lee KW, Georget V, Rassinier P, Leader B, Verlhac MH. Spindle positioning in mouse oocytes relies on a dynamic meshwork of actin filaments. Curr Biol. 2008;18:1514-1519.

Bettencourt-Dias M, Glet R, Sinka R, Mazumdar A, Lock WG, Balloux F, Zafiropoulos PJ, Yamaguchi S, Winter S, Carthew RW, Cooper M, Jones D, Frenze L, Glover DM. Genome-wide survey of protein kinases required for cell cycle progression. Nature. 2004;432:980-987.

Bonaccorsi S, Mottier V, Giansanti MG, Bolkan Bj, Williams B, Goldberg ML, Gatti M. The Drosophila Lkb1 kinase is required for spindle formation and asymmetric neuroblast division. Development. 2007;134:21832193.

Bultot L, Horman S, Neumann D, Walsh M, Hue L. Myosin light chains are not a physiological substrate of AMPK in the control of cell structure changes. FEBS Lett. 2009;583:25-28.

Campbell EM, Hope TJ. Role of the cytoskeleton in nuclear import. Adv Drug Deliv Rev. 2003;55:761-771.

Carling D. The AMP-activated protein kinase cascade--a unifying system for energy control. Trends Biochem Sci. 2004;29:18-24.

Chen J, Hudson E, Chi MM, Chang AS, Moley KH, Hardie DG, Downs SM. AMPK regulation of mouse oocyte meiotic resumption in vitro. Dev Biol. 2006;291:227-238.

Zygote, Vol. 22, No. 1 (February 2014): pg. 91-102. DOI. This article is (C) Cambridge University Press and permission has been granted for this version to appear in e-Publications@Marquette. Cambridge University Press does not grant permission for this article to be further copied/distributed or hosted elsewhere without the express permission from Cambridge University Press. 
NOT THE PUBLISHED VERSION; this is the author's final, peer-reviewed manuscript. The published version may be accessed by following the link in the citation at the bottom of the page.

Chen J, Downs SM. AMP-activated protein kinase is involved in hormoneinduced mouse oocyte meiotic maturation in vitro. Dev Biol. $2008 ; 313: 47-57$.

Combelles $\mathrm{CMH}$, Albertini DF. Microtubule Patterning during Meiotic Maturation in Mouse Oocytes Is Determined by Cell Cycle-Specific Sorting and Redistribution of $Y$-Tubulin. Dev Biol. 2001;239:281-294.

Ding J, Swain JE, Smith GD. Aurora kinase-A regulates microtubule organizing center (MTOC) localization, chromosome dynamics, and histone-H3 phosphorylation in mouse oocytes. Mol Reprod Dev. 2011;78:80-90.

Downs SM, Ya R, Davis CC. Role of AMPK throughout meiotic maturation in the mouse oocyte: evidence for promotion of polar body formation and suppression of premature activation. Mol Reprod Dev. 2010;77:888899.

Downs SM, Chen J. Induction of meiotic maturation in mouse oocytes by adenosine analogs. Mol Reprod Dev. 2006;73:1159-1168.

Dumont J, Million K, Sunderland K, Rassinier P, Lim H, Leader B, Verlhac MH. Formin-2 is required for spindle migration and for the late steps of cytokinesis in mouse oocytes. Dev Biol. 2007;301:254-265.

Giannakakou P, Sackett DL, Ward Y, Webster KR, Blagosklonnyu MV, Fojo T. p53 is associated with cellular microtubules and is transported to the nucleus by dynein. Nature Cell Biol. 2000;2:709-717.

Hardie DG. Minireview: the AMP-activated protein kinase cascade: the key sensor of cellular energy status. Endocrinology. 2003;144:5179-5183.

Inoue M, Naito K, Nakayama T, Sato E. Mitogen-activated protein kinase translocates into the germinal vesicle and induces germinal vesicle breakdown in porcine oocytes. Biol Reprod. 1998;58:130-136.

Jansen M, Ten Klooster JP, Offerhaus GJ, Clevers H. LKB1 and AMPK family signaling: the intimate link between cell polarity and energy metabolism. Physiol Rev. 2009;89:777-798.

Karaiskou A, Leprêtre A-C, Pahlavan G, Pasquier, Du D, Ozon R, Jessus C. Polo-like kinase confers MPF autoamplification competence to growing Xenopus oocytes. Development. 2004;131:1543-1552.

Zygote, Vol. 22, No. 1 (February 2014): pg. 91-102. DOI. This article is @ Cambridge University Press and permission has been granted for this version to appear in e-Publications@Marquette. Cambridge University Press does not grant permission for this article to be further copied/distributed or hosted elsewhere without the express permission from Cambridge University Press. 
NOT THE PUBLISHED VERSION; this is the author's final, peer-reviewed manuscript. The published version may be accessed by following the link in the citation at the bottom of the page.

Kodiha M, Rassi JG, Brown CM, Stochaj U. Localization of AMP kinase is regulated by stress, cell density, and signaling through the MEK>ERK1/2 pathway. Am J Physiol Cell Physiol. 2007;293:C1427-C1436.

Koh $\mathrm{H}$, Chung J. AMPK links energy status to cell structure and mitosis. Biochem Biophys Res Commun. 2007;362:789-792.

Lam MHC, Thomas RJ, Loveland LK, Schilders S, Gu M, Martin TJ, Gillespie MT, Jans DA. Nuclear transport of parathyroid hormone (PTH)-related protein is dependent on microtubules. Mol Endocrinol. 2002;16:390401.

LaRosa C, Downs SM. Meiotic induction by heat stress in mouse oocytes: involvement of AMP-activated protein kinase and MAPK family members. Biol Reprod. 2007;76:476-486.

Lee JH, Koh H, Kim M, Kim Y, Lee SY, Karess RE, Lee SH, Shong M, Kim JM, $\mathrm{Kim} \mathrm{J}$, et al. Energy-dependent regulation of cell structure by AMPactivated protein kinase. Nature. 2007;447:1017-1020.

Liu SM, Liu WM. Recent developments in the understanding of nuclear protein import. Protein and Peptide Lett. 2007;14:723-733.

Lu Z, Dunn RL, Angeles R, Smith GD. Regulation of spindle formation by active mitogen-activated protein kinase and protein phosphatase $2 \mathrm{~A}$ during mouse oocyte meiosis. Biol Reprod. 2002;66:29-37.

Ma C, Cummings $\mathrm{C}$, Liu XJ. Biphasic activation of Aurora-A kinase during the meiosis I- meiosis II transition in Xenopus oocytes. Mol Cell Biol. $2003 ; 23: 1703-1716$.

Ma W, Koch J. Protein Kinase C delta (PKC [delta]) interacts with microtubule organizing center (MTOC)-associated proteins and participates in meiotic Spindle Organization. Dev Biol 2008.

Maro B, Howlett SK, Webb M. Non-spindle microtubule organizing centers in metaphase II-arrested mouse oocytes. J Cell Biol. 1985;101:16651672.

McGee SL, Howlett KF, Startkie RL, Cameron-Smith D, Kemp BE, Hargreaves $M$. Exercise increases nuclear AMPK $a_{2}$ in human Skeletal muscle. Diabetes. 2003;52:926-928.

Zygote, Vol. 22, No. 1 (February 2014): pg. 91-102. DOI. This article is (C) Cambridge University Press and permission has been granted for this version to appear in e-Publications@Marquette. Cambridge University Press does not grant permission for this article to be further copied/distributed or hosted elsewhere without the express permission from Cambridge University Press. 
NOT THE PUBLISHED VERSION; this is the author's final, peer-reviewed manuscript. The published version may be accessed by following the link in the citation at the bottom of the page.

Merdes A, Heald R, Samejima K, Earnshaw WC, Cleveland DW. Formation of spindle poles by dynein/dynactin-dependent transport of NuMA. J Cell Biol. 2000;149:851-862.

Messinger SM, Albertini DF. Centrosome and microtubule dynamics during meiotic progression in mouse oocyte. Journal of cell science. 1991;100:289-298.

Mirouse V, Swick LL, Kazgan N, St Johnston D, Brenman JE. LKB1 and AMPK maintain epithelial cell polarity under energetic stress. J Cell Biol. 2007; 177:387-392.

$\mathrm{Na} \mathrm{J}$, Zernicka-Goetz M. Asymmetric positioning and organization of the meiotic spindle of mouse oocytes requires CDC42 function. Current Biology. 2006;16:1249-1254.

Oh JS, Han SJ, Conti M. Wee1B, Myt1, and Cdc25 function in distinct compartments of the mouse oocyte to control meiotic resumption. ] Cell Biol. 2010;188:199-207.

Pines J. Four-dimensional control of the cell cycle. Nature Cell Biol. 1999;1:E73-E79.

Rathinasamy K, Panda D. Kinetic stabilization of microtubule dynamic instability by benomyl increases the nuclear transport of p53. Biochem Pharmacol. 2008;76:1669-1680.

Rime $\mathrm{H}$, Jessus $\mathrm{C}$, Ozon R. Estramustine phosphate inhibits germinal vesicle breakdown and induces depolymerization of microtubules in mouse oocyte. Reprod Nutr Develop. 1988;28(2A):319-334.

Ruchaud S, Carmena M, Earnshaw WC. Chromosomal passengers: conducting cell division. Nat Reviews Mol Cell Biol. 2007;8:798-812.

Salman H, Abu-Arish A, Oliel S, Loyter A, Klafter J, Granek R, Elbaum M. Nuclear localization signal peptides induce molecular delivery along microtubules. Biophys J. 2005;89:2134-2145.

Schatten h, Schatten G, Mazia D, Balczon R, Simerly C. Behavior of centrosomes during fertilization and cell division in mouse oocytes and sea urchin eggs. Proc Natl Acad Sci USA. 1986;83:105-109.

Zygote, Vol. 22, No. 1 (February 2014): pg. 91-102. DOI. This article is @ Cambridge University Press and permission has been granted for this version to appear in e-Publications@Marquette. Cambridge University Press does not grant permission for this article to be further copied/distributed or hosted elsewhere without the express permission from Cambridge University Press. 
NOT THE PUBLISHED VERSION; this is the author's final, peer-reviewed manuscript. The published version may be accessed by following the link in the citation at the bottom of the page.

Stewart M. Molecular mechanism of the nuclear protein import cycle. Nature Rev. 2007;8:195-208.

Sun QY, Schatten H. Regulation of dynamic events by microfilaments during oocyte maturation and fertilization. Reproduction. 2006;131:193-205.

Sun SC, Xiong B, Lu SS, Sun QY. MEK1/2 is a critical regulator of microtubule assembly and spindle organization during rat oocyte meiotic maturation. Mol Reprod Dev. 2008;75:1542-1548.

Sun SC, Wei L, Li M, Lin SL, Xu BZ, Liang XW, Kim NH, Schatten H, Lu SS, Sun QY. Perturbation of survivin expression affects chromosome alignment and spindle checkpoint in mouse oocyte meiotic maturation. Cell Cycle. 2009;20:3365-3372.

Szczepańska K, Maleszewski M. LKB1/PAR4 protein is asymmetrically localized in mouse oocytes and associates with meiotic spindle. Gene Expr Patterns. 2005;6:86-93.

Tong C, Fan HY, Lian L, Li SW, Chen DY, Schatten H, Sun QY. Polo-like kinase-1 is a pivotal regulator of microtubule assembly during mouse oocyte meiotic maturation, fertilization, and early embryonic mitosis. Biol Reprod. 2002;67:546-554.

Uteng M, Hentrich C, Miura K, Bieling P, Surrey T. Poleward transport of Eg5 by dynein-dynactin in Xenopus laevis egg extract spindles. J Cell Biol. 2008; 182:715-726.

Uzbekova S, Arlot-Bonnemains Y, Dupont J, Dalbies-Tran R, Papillier P, Pennetier $S$, lieAurore $T$, Perreau $C$, Mermillod $P$, Prigent $C$, et al. Spatio-Temporal Expression Patterns of Aurora Kinases A, B, and C and Cytoplasmic Polyadenylation-Element-Binding Protein in Bovine Oocytes During Meiotic Maturation. Biol Reprod. 2008;78:218-233.

Van Blerkom K, Bell H. Regulation of development in the fully grown mouse oocyte: chromosome-mediated temporal and spatial differentiation of the cytoplasm and plasma membrane. J Embyol Exp Morph. $1986 ; 93: 213-238$.

Vazquez-Martin A, Oliveras-Ferraros C, Menendez JA. The active form of the metabolic sensor: AMP-activated protein kinase (AMPK) directly binds the mitotic apparatus and travels from centrosomes to the spindle

Zygote, Vol. 22, No. 1 (February 2014): pg. 91-102. DOI. This article is (C) Cambridge University Press and permission has been granted for this version to appear in e-Publications@Marquette. Cambridge University Press does not grant permission for this article to be further copied/distributed or hosted elsewhere without the express permission from Cambridge University Press. 
NOT THE PUBLISHED VERSION; this is the author's final, peer-reviewed manuscript. The published version may be accessed by following the link in the citation at the bottom of the page.

midzone during mitosis and cytokinesis. Cell Cycle. 2009;8:23852398.

Vazquez-Martin A, Oliveras-Ferraros C, Cufi S, Menendez JA. Polo-like kinase 1 regulates activaiton of AMP-activated proteinn kinase (AMPK) at the mitotic apparatus. Cell Cycle. 2011;10:1295-1302.

Viveiros MM, Hirao Y, Eppig JJ. Evidence that protein kinase C (PKC) participates in the meiosis I to meiosis II transition in mouse oocytes. Dev Biol. 2001;235:330-342.

Wagstaff KM, Jans DA. Importins and beyond: non-conventional nuclear transport mechanisms. Traffic. 2009;10:1188-1198.

Wianny F, Tayares A, Evans MJ, Glover DM, Zernicka-Goetz M. Mouse pololike kinase 1 associates with the acentriolar spindle poles, meiotic chromosomes and spindle midzone during oocyte maturation. Chromosoma. 1998;107:430-439.

Williams T, Brenman JE. LKB1 and AMPK in cell polarity and division. Trends Cell Biol. 2008;18:193-198.

Yang KT, Li SK, Chang CC, Tang CJC, Lin YN, Lee SC, Tang TK. Aurora-C Kinase Deficiency Causes Cytokinesis Failure in Meiosis I and Production of Large Polyploid Oocytes in Mice. Molecular Biology of the Cell. 2010;21:2371-2383.

Yao L, Zhong Z, Zhang L, Chen D, Schatten H, Sun Q. Aurora-A is a critical regulator of microtubule assembly and nuclear activity in mouse oocytes, fertilized eggs, and early embryos. Biol Reprod. $2004 ; 70: 1392-1399$.

Yuan J, Li M, Wei L, Yin S, Xiong B, Li S, Lin SL, Schatten H, Sun QY. Astrin regulates meiotic spindle organization, spindle pole tethering and cell cycle progression in mouse oocytes. Cell Cycle. 2009;8:3384-3395.

Zhang S, Schafer-Hales K, Khuri FR, Zhou W, Vertino PM, Marcus AI. The Tumor Suppressor LKB1 Regulates Lung Cancer Cell Polarity by Mediating cdc42 Recruitment and Activity. Cancer Research. 2008;68:740-748.

Zygote, Vol. 22, No. 1 (February 2014): pg. 91-102. DOI. This article is (C) Cambridge University Press and permission has been granted for this version to appear in e-Publications@Marquette. Cambridge University Press does not grant permission for this article to be further copied/distributed or hosted elsewhere without the express permission from Cambridge University Press. 